\title{
The E-commerce Era: A Qualitative Study on the Growth Strategies of Online Business among Philippine School Doha Senior High School Students
}

\author{
Joan Marie T. Alegario, MST a,b,c , Angela Nina J. Aldover a,b,c James Bryan M.
} Bondad a,b,c , Genale Audrey V. Calpito a,b,c, Julianne Kyle A. Cañeso a,b,c , Frank Gio S. Cruz ${ }^{\text {a,b,c }}$, Gabrielle Mogene D. Olaes a,b,c , Elysha Reigne S. Santos a,b, Ralph Fredie M. Tomas a,b,c

${ }^{a}$ Philippine School Doha, Doha, Qatar

${ }^{b}$ Research Development, Accreditation and Publication Office, PSD, Doha, Qatar

${ }^{c}$ Research Capstone Project, PSD, Doha, Qatar

\begin{abstract}
Background: Social media has been an influential platform for young adults. Hence, along the growth of ecommerce; young adults recognize the potential of putting up an online business. However, a business involves a series of challenges that put these young adults to the test. This study then aims to identify the growth strategies of student online sellers and how they cope with the responsibilities of having an online business. Method: This study utilized the phenomenological approach as it sought to understand the lived experiences of student online sellers relative to the central question: "What are the challenges commonly faced by a Philippine School Doha Senior High School Student who is into online business?". Data gathered were analyzed using an inductive approach. Findings: Findings have shown that challenges in an online business are inevitable, however, online selling reveals the capabilities of students to become successful entrepreneurs as they learn to overcome any challenge that may come along their way. Conclusion: Their familiarity with social media platforms creates an advantage for them to start a business. Handling a business serves as a transcendent opportunity for these students as the strategies they develop benefits not only their business but also their personal lives. Recommendation: This paper recommends the young adults to enable themselves to be knowledgeable of the aspects behind the strategies of online businesses which can greatly influence one's idea about entrepreneurship. Future related studies should further expand on the concept of ecommerce as it can help establish a wider perspective on the several opportunities it offers to the youth.
\end{abstract}

Keywords: Online Selling; Growth Strategies; Young Entrepreneurs; Financial Literacy; E-commerce; Student Online Seller

\section{Introduction}

Technology has significantly contributed to the modernized world as it has helped in realizing the potential of managing a business online. E-commerce is a new business technology model in the world as it prompted a significant change in the mode of production and services of the whole world (Elnaga \& $\mathrm{Al}$ Shammari, 2016). E-commerce, also known as electronic commerce, introduces the concept of managing a business through the web. Correspondingly, it deals with the exchange of cash online. E-commerce is used to refer to the online availability of physical goods, yet it can likewise depict any business exchange encouraged through the web. 
Due to the high popularity of the Internet and the rapid development of e-commerce, more consumers are willing to purchase products online $(\mathrm{Ou}, 2015)$. Online selling is the process of purchasing and selling products online. Along with its development, online selling has become prevalent to society because of the convenience of ordering an item and having it delivered efficiently on their doorstep. Online selling has highlighted the ease of putting up a business and gaining profit from it even at a young age. Setting up a business has made entrepreneurs creative in promoting their products and being flexible in interacting with other customers. Furthermore, online selling can save time for both the client and retailer, diminishing calls about openness, specifics, significant length of action, or other information viably found on association and thing pages (Hartley, 2016).

With the progress of online selling into various social media platforms, it has provided the youth an opportunity to fulfill their dreams and build their future through online business potentials. Moreover, with the developments of online selling, young adults involved in the scene become more prepared to handle finances independently. Student online sellers are those who partake in the process of selling goods, products, or services with the use of e-commerce as their platform. Student online sellers often engage in any commercial transaction that is facilitated through the Internet. Being born into the modernized era, these student online sellers find online selling interesting as they are familiar with the internet world. Competition in the business field develops since it is easier for students to access and establish a business that heightens the sellers' marketing and trading strategies. The e-commerce era helps student online sellers enhance their skills in their academics and future careers.

As online selling starts to grow and become more popular, it captures the attention of the youth. These youths are raised in an electronic-filled society with an online and socially networked world; youth become addicted to mobile phones and services (Ravichandran, 2018). Furthermore, growing up in a modernized world made these student online sellers interested in the potentials of earning their own money online. As adolescence is an impressionable age or role models replicating stage, they take them from all areas close at hand in their society, including the world of social media (Punia, 2015). Subsequently, teenagers like these student online sellers have grown accustomed to the world of the Internet that makes them aware of the current trends that could attract customers. These student online sellers have learned to develop healthy and efficient strategies to boost their small online businesses at an early age.

In any business undertaking, challenges would undoubtedly be faced along the way. It requires an efficient business strategy to be able to achieve the best outcome in every situation. Hence, this captured the researchers' attention to focus on the challenges commonly faced by student online sellers of Philippine School Doha. Their personal experiences are a vital part of this research study's development as it provides an opportunity for the researchers and the readers to gain more insight into the growth strategies that helped them achieve success in the e-commerce platform. This research's central focus is to find out how student online sellers cope with the challenges they have faced in doing online selling.

This research paper provides young entrepreneurs a wider perspective on handling an online business as they approach accomplishments in their business ventures. The participants of this study showcased the strategies, plans, and tactics needed to succeed in the business field. The study emphasized on the student online seller's capabilities to overcome the challenges that are involved in online selling. Their ability to develop efficient strategies directed them to the growth of their small businesses.

The readers, especially those student online sellers, can use this research study as a guide for them to follow on how to start up their own online business Moreover, this study also provides student online sellers the necessary information that they can use for their own online business. The results from this study can 
benefit not only student online sellers but also aspiring online entrepreneurs that are interested with ecommerce.

In this study, responses were thoroughly analyzed and four major themes emerged: (1) Establishing the potentials of becoming a young entrepreneur through several skills obtained (2) Acquiring the values necessary to become a successful online seller (3) Identifying the expenses and handling the flow of their money properly (4) Understanding the perspective of their market. The strategies identified in the study can be useful for future online sellers as they venture into the business field. The study emphasized how determined the student online sellers are despite all the challenges that entails an online business.

This research study utilized the qualitative approach, following the IMRAD format, to gain further knowledge from the opinions and experiences of the participants. Furthermore, to deeply understand the lived experiences of student online sellers, the researchers conducted a twenty-five semi-structured interview. The responses from the participants were collected through recording devices. The researchers translated the responses from emic to etic to get the main idea of the participants. With the approach of this study, the researchers were able to identify the challenges and the strategies that student online sellers integrate into their online business.

\section{Methods}

\subsection{Research Design}

This qualitative research method utilized a phenomenological approach as it sought to study the participants' lived experiences and behavior. According to Dela Cruz, et al. (2020), the Phenomenological approach is highly substantial in understanding subjective experiences and gaining insights into people's motivations and decisions. This approach allows the researcher to suspend their own assumptions on what is right or wrong, what makes sense or makes no sense, and seek to look at the world through the participants' eyes (Willig, C., 2016). Qualitative research is the collection of data and analysis, interview transcripts, oral reports, videos of social interactions, drawings, etc., without using non-numerical data (Packer, M. J.,2017). A qualitative method is driven by a research question that identifies the focus of the research. Qualitative research questions are cored with actions rather than causes or effects (Willig, C., 2016). In this study, the researchers aimed to collect data through comprehensive interviews to understand the student online sellers' experiences regarding the challenges they faced in online selling and how they cope with those business struggles.

\subsection{Research Locus and Sample}

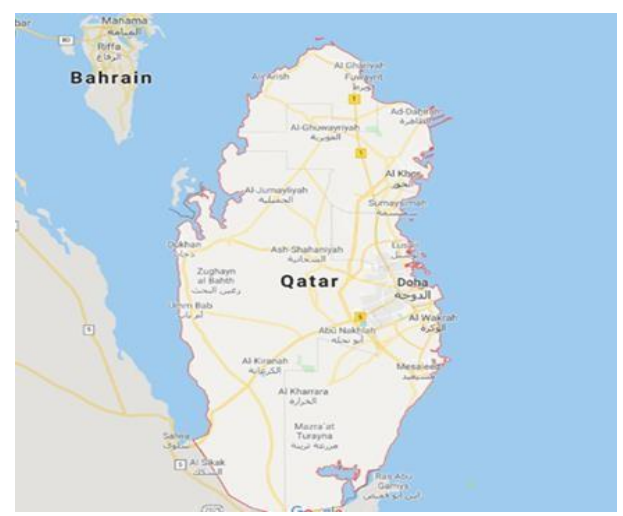

This study was conducted at Philippine School Doha (PSD), a prominent Filipino educational community that is located in Doha, Qatar. This educational establishment is known for its quality service and excellence that serves the Filipino community in Qatar. The researchers chose PSD due to its practicable access that is beneficial to the researchers.

Six Senior High School students with online businesses served as the participants of this study. These participants were selected through qualitative purposive sampling strategy. In the selection of the participants, the researchers considered the number of years the student online seller has been doing the

\footnotetext{
Figure 1: Map of Qatar
}

Taken cc: Google Maps 
business. It should be over a year of experience in handling business. These participants run their own online business, which will greatly exhibit their strategies in managing and handling challenges of online selling. The kind of business our participants own is mostly online shops utilizing Instagram.

\subsection{Data Collection and Ethical Consideration}

Two instruments were utilized to collect the needed information for the study. The researchers made use of the robotfoto to acquire the participant's demographics. A robotfoto refers to the personal data sheets of the participants (Guzman \& Tan, 2007; Dipasupil, et. al., 2020). This includes the name, age, gender and years that the business has been established.

The twenty-five semi-structured interview guide was also developed in order to gain knowledge and see other perspectives based on the lived experiences of the participants. The respondent's verbatim responses were collected through the use of a recording device.

The participant's approval to participate in the study was sought first through the use of the consent letters that were given to them prior to the conduct of the interviews. Confidentiality was assured and sustained throughout the gathering the information and was only shared with the research committee involved.

\subsection{Data Analysis}

The inductive approach for phenomenological data analysis was observed in this research. The researchers have followed an inductive approach wherein an interview has been conducted to narrow the scope of the study in developing themes (Ryan, 2003; Vallesteros, 2018) as cited by (Dela Cruz et al., 2020).

The researchers employed the inductive approach which included: (1) Transcribing responses into written text; (2) Interpreting the responses of each participant into the researcher's own understanding; (3) Examining the responses to gain insights on the participant's experience; (4) Categorizing interpreted responses with similar concepts and creating a thought unit; (5) Formulating thought units into themes to form a dendrogram; (6) Constructing a simulacrum that serves as a visual aid to explain the gathered results; (7) Concluding transcriptions by conducting member-checking procedure to strengthen the credibility of the paper (EvaSys, 2019; Dipasupil, P. et. al, 2020).

\section{Findings}

This phenomenological study discusses the strategies of online businesses among student online sellers concerning the growth and values acquired relative to the central question: "What are the challenges commonly faced by a Philippine School Doha Senior High School Student who is into an online business?". Furthermore, this study focused on the specific question: "How do Philippine School Doha Senior High School students cope with their online business struggles?". With the progress of e-commerce into the economy, it captured these business-minded students' attention, which has provided them the opportunity to become young and smart entrepreneurs in the future. Furthermore, venturing into online business at an early age has made them financially aware and independent as they face the struggles of managing a business.

Figure 2 shows the simulacrum focused on four major themes: establishing potentialities, acquiring values, regulating expenses, and understanding customers. These themes highlight the various strategies that student online sellers develop while conducting their online business. Moreover, the themes are connected to 
the potentials, values, and skills observed by a student online seller.

The simulacrum has the element of balance with various components that showcase the meaning of each shape and color. First, the outermost circle is a blank space that holds the other elements of the simulacrum which also signifies the valor and confidence of the student online sellers to enter a competitive business field.

The simulacrum emphasizes the strategies that the student online sellers developed while doing online selling. Firstly, the puzzle-like shapes that connect the themes represent their determination to continue their venture into online business despite the challenges that come along the way. Their determination keeps their business afloat,

helping them grow to become more successful in the

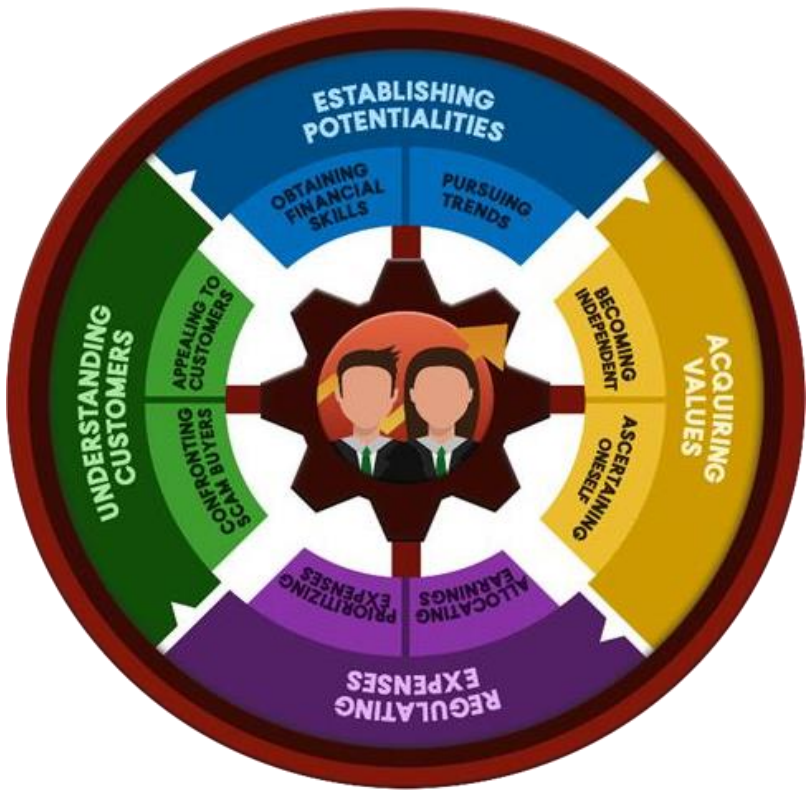

Figure 2: Simulacrum

Growth Strategies of PSD SHS Student Online Sellers future. Secondly, under the significant theme are sub-

themes that support the significance of the major themes. Thirdly, the colors of the themes represent the Senior High School academic strands, Green for STEM, Yellow for ABM, Violet for GAS, Blue for HUMSS, which embody the diversity of different kinds of students that invest their time into an online business. Fourthly, the gear-like shape in the middle signifies their effort into making their online business work and become successful despite the many responsibilities they have as a student and an online seller. Lastly, the two students placed in the middle of the gear represent the SHS Students, and the arrow behind them symbolizes their goals related to the growth of their online business. To summarize, the symbols used in the simulacrum are connected to student online sellers' growth strategies and how they persevere to create a successful online business despite the challenges.

\subsection{Establishing Potentialities}

Nowadays, social media is the most efficient tool to instantly share and create ideas. With it being prevalent into the lives of the youth, some grow interested in the potentials of venturing into the world of online business. Being in the adolescent stage, these student online sellers have developed a mind-set that they want to be able to prove something to the people around them. Having the opportunity to start a business has given these student online sellers the platform to pursue the potentials of becoming an entrepreneur at a young age. Online selling has helped these student online sellers gain a wider perspective about e-commerce rooting from the financial skills that they have obtained to the increased knowledge about their business and its potential.

\section{Obtaining Financial Skills}

Venturing into the world of business is a huge milestone for these student online sellers. Being immersed into e-commerce, it has helped them develop the skills that are necessary for an entrepreneur. These young 
entrepreneurs gained knowledge in budgeting and personal discipline to harmonize with their business.

"I think I obtained a skill which is budgeting and from my early age as now, it's a good skill to acquire because it made me independent from my parents and as teens, it's hard for us to discipline ourselves when it comes to saving money and budgeting especially when we focus on the trends". (P2)

"Before I just keep on buying things because I do not understand the importance of money but now I learned how to budget money". (P4)

Being able to obtain skills as young as these student online sellers is a great achievement, as it creates an opportunity for them to become financially independent. With the skills acquired from online selling, these student online sellers found ways to innovate new strategies for their online business in order to improve the quality of their business. These student online sellers obtain knowledge in establishing financial decisions that they use in their daily lives and investment opportunities.

"It helped me financially because the money I invest in selling goes back to me". (P1)

"It helped me have extra income that I can use for myself and I was able to create more to continue my store". (P6)

In addition, these student online sellers learn to invest into the business profitability potential that can generate and widen their market. With this, they acquire knowledge in investing and maintaining the inflow and outflow of the money that is being generated.

\section{Pursuing Trends}

A difficult stage in managing a business is deciding what products to sell as there are several things to consider, such as the profitability and quality of the product. Nowadays, teenagers like these student online sellers are always online as their lives revolve around social media. Being familiar with how the internet works and being aware of its trends is a great advantage for these teenagers as they are allowed to pursue the potentials of putting a particular product on the market.

"Collecting sneakers is my hobby so I think it is easier for me to sell online since it is also my interest and it is easy for me to find customers for it". (P2)

"The reason behind my online selling is because I wanted to buy a BTS ticket last 2017 which inspired me more to sell online." (P3)

"The other reason was because there are a lot of kpop fans in our school who couldn't purchase kpop related items and since I was selling Korean albums I thought of them. I also wanted a job at that time, that's why I decided to do online selling". (P6)

Student online sellers can widen their market by determining the current trends that the customers want to see. Moreover, most student online sellers get product ideas based on their personal needs and want as a significant population of their target market falls under the same age bracket. Business requires different knowledge and training that can help achieve the desired success. Knowing and studying a chosen market can provide a good outcome for both the seller and the online business. In managing a business, one must determine the market trends as it is the key to the growth and success of the business. Being able to establish the potentialities of trends can be a risk to a small business. However, it can also be a strategy that can help 
uplift the success of the business.

\subsection{Acquiring Values}

Values reflect the most cherished ideals of an individual as it guides one's actions and decisions. The development of values of an individual is influenced by the world around them as well. Involving oneself in business can make an individual grow more mature and independent as they learn to weigh what matters the most in a particular situation. Being immersed in online business at an early age has helped these student online sellers feel independent as they learn how to practice the skills in organization and time management on their own. Learning management skills can contribute to one's independence as they can balance their responsibilities in life.

\section{Becoming Independent}

As young adults, these student online sellers have to fulfill multiple responsibilities, and they often find themselves troubled with how they should balance all responsibilities. However, despite the struggles, they continue to become young entrepreneurs as they realize the ease of putting up an online business. Consequently, this entails them to learn how to be independent for they can realize their capabilities as an individual and as an entrepreneur.

"Online selling is a low set up business with less time intensive which help me manage my time with my academics and still do online selling that also helps me to have an income”. (P2)

Being young adults, it can be not easy to maintain all responsibilities properly. However, with online selling, one can manage both responsibilities because of the low set up that online selling requires. Online selling allows sellers to become flexible in handling all their responsibilities. Moreover, this has helped in developing independence for these student online sellers.

"Not financially stable, but the income I get from online selling, I use it as an extra fund for my daily expenses”. (P3)

"Since I don't have an allowance, I am the one budgeting my expenses that why I became more independent”. (P4)

Learning how to handle finances at a young age helped mold these student online sellers into the successful young entrepreneurs they have become. The skills they have acquired while doing online selling contributed to their growth as young adults. Furthermore, online selling has helped them grow mature and independent.

Subsequently, the impact of domestic matters has also helped these student online sellers continue their journey in e-commerce. With the support from their families, they became more motivated to pursue their online business's success as they realize that earning money from it can help the family financially.

“It made me independent from my parents because I am now able to earn money from my own”. (P1)

"It has helped me become independent, but I can also see that they are supporting me in online selling as well”. (P5) 
As online sellers, they learn how to handle different situations that widen their financial, communication, and organizational skills. The skills that they have acquired while conducting an online business provided them the opportunity to grow independently. Being involved in e-commerce has helped improve their entrepreneurial skills and has helped them handle situations professionally.

\section{Ascertaining Oneself}

Involving oneself into the world of business can be a challenge for these young entrepreneurs since earning money can make them feel pressured as they are the ones responsible for every action they would take for their small business.

However, when young entrepreneurs fall flat, they have substantially more opportunity to learn and reboot, unlike individuals in their 40's who have significantly less. It implies more opportunities to succeed. Additionally, youthful business people have less duty regardless of whether it may be monetary responsibilities that include home loans, family, children, and in this manner, they are significantly more liable to face challenges that lead to progress.

"Although, I am not that secured of my future but knowing that I was able to run a business by myself, it gave me a good feeling that I can do things which doesn't require the guidance of my parents". (P6)

Student online sellers have also learned how to appreciate themselves with the time and effort into online selling. With their efforts, they molded themselves to become skilled and competent individuals, opening the door for numerous opportunities. Additionally, realizing their capabilities as an individual serve as a motivating factor for them to continue their venture into e-commerce.

"I think I obtained a skill which is budgeting and from my early age as now, it's a good skill to acquire because it made me independent from my parents and as teens, it's hard for us to discipline ourselves when it comes to saving money and budgeting especially when we focus on the trends". (P2)

"Budgeting and patience, because it is hard if there are a lot of orders so I need to finish it so that I can wrap and deliver it the next day, discipline and patience is needed". (P4)

Being able to discipline oneself is a value that an entrepreneur must be able to acquire as it can play a crucial role in a business's success. Teens can find it difficult to discipline themselves as they tend to focus on the trends they want to follow; however, with these student online sellers, they learn how to discipline themselves and hold the virtue of patience. Having patience is an essential virtue for an online seller as there can be several scams and bogus buyers that would deceive them. Having the virtue of patience can help them in handling professionally the scam buyers. An entrepreneur needs to handle things professionally as it can significantly impact the business if a particular situation would go wrong.

"I think I have few which is patience, trust and respect. Patience because you should not be aggressive when selling online. Trust because other market sources or buyers will rely on you if you maintain a good service in delivering the products, the last thing is respect". (P2)

Maintaining the right attitude makes positive initial introductions, leading to deeper personal and professional connections with the customers. It creates a broader opportunity for the business as it develops the customers' trust and the business's people. The virtues that an online seller should maintain can benefit the business in the long run. 


\subsection{Regulating Expenses}

Managing one's finances plays a crucial role in a business's life as it keeps the business alive. Finances are considered the heart of a business as it deals with the inflow and outflow of cash. In small businesses like online shops, their business' cash flow is the most critical factor since earning a sufficient profit is the main goal they have set for their online shop.

\section{Prioritizing Expenses}

Overseeing the flow of cash into the business helps these online sellers properly allocate the money and determine the expenses they should prioritize first for the sake of the success of their shop.

“You just need to keep buying products to sell so that the money will continue to flow”. (P3)

"Whenever I sell, most of my savings for that month will be used for my selling next month, so I use it as my capital for the upcoming month". (P4)

"I don't spend most of my expenses actually. I just put it in my savings and allot a certain amount of money to buy a next set of products". (P6)

Entering the field of business will require these young entrepreneurs to learn much financial knowledge. Knowing about budgeting, saving, and investing is a behavior that an online seller must grasp as it is key to creating a successful online business. These online sellers handle two types of finances; business and personal finances.

"The income I get from online selling goes to my savings. I think 80 percent of it goes to my savings and 20 percent of it is budgeted for my necessities". (P2)

"I separate the money that I earn from the shop and the money I own so that I will determine where my expenses go”. (P3)

"I divide my income; I keep aside 50\% of my profit and the remaining 50\% I use it for my expenses". (P5)

In addition, being able to determine and separate the two types of finances from each other is crucial in computing the income, expenses and savings.

\section{Allocating Earnings}

Online sellers have established a strategy that aims to identify the various expenses involved when managing an online business. There are many expenses to be considered when entering a business that is needed to put on account to keep track of the expenses that their business encounters. Moreover, tracking the expenses of the shop helps in deciding where the earnings would be placed. (P1)

"I write down all the expenses and the things that I have sold in order to control the flow of my money".

"I list all the costs and expenditures I do during online selling, for me to be notified and clear of my items 
and other things I have sold from the past”. (P2)

"I write my expenses first so that I can be able to calculate my profit and from that profit I would sell and prioritize my expenses". (P6)

In any business, financial risk will always be present because of different aspects. These young entrepreneurs entered online selling with the knowledge of different expenses that they would undoubtedly encounter. Expenses for their products, shipping, and packaging are being noted down to regulate and match their sales return. (P5)

"I write and audit everything so that I would be informed and so there would be no wrong calculations".

"I make sure not to consume the money just for my personal use but also setting aside some for continuing my online business". (P6)

Furthermore, personal expenses are also a factor to be considered when students enter the business field because this will promote their entrepreneurship and young adult development. As an online seller, they have the authority to decide where the earnings generated from the business would go, whether they decide to put it into their savings or use it as capital to continue their shop. Having the ability to organize their finances and separate them from personal and business is essential for their growth as a young entrepreneur. Identifying the difference between the two can create ease in handling one's finances.

Businesses depend on finances primarily because it helps determine whether the business gains profit or simply has losses. In managing finance, it is necessary to keep track of the expenses as every amount matter, particularly for small businesses like online shops.

\subsection{Understanding Customers}

In owning a small business, one must ensure that everything being offered would satisfy the market's desires. Each customer has a unique behavior in buying online. These customers can be a basis for the mode of approach that the student online sellers can incorporate into their shop.

\section{Confronting Scam Buyers}

Scam buyers would so often deceive the seller, letting them think that they are interested in buying. For online sellers like these students, there are times that they are unable to detect a scam buyer. With this, online sellers must be careful in trusting their buyers to be a possible scam buyer.

"It is very important to be careful because there are some instances that they use other pictures or information used for scamming". (P1)

However, it is certain that there would be scam buyers in the world of business and often being careful is not enough to prevent getting scammed.

"As I have said before, the sneaker market is big where in you can vouch the buyer. There are other people who would also point out a buyer if he/she is a real buyer or not". (P2) 
"It is important to be careful since I sell my products through Instagram. I check if the profile is active to determine if it is a real person because usually a random account does not have followers and will make you think whether they will really buy it or not". (P6)

Social media can be a significant opportunity for a business. However, it still makes a business vulnerable and susceptible to scam. The advancements of technology may be beneficial, but it poses a threat to a small business like the students' online shops.

Moreover, online sellers have developed a strategy that has helped them deal with scam buyers professionally. Validating the authenticity and intention of a buyer helps in avoiding problems like a scam. Keeping a lookout can limit the possibilities of scam buyers and losses.

"I deal with scam buyers by talking to them in person or by call. I want to make sure that they are serious in buying an item." (P1)

"I'd ask the buyers information and sometimes tell them ahead of time that no cancellation of orders is allowed”. (P5)

Dealing with scam can greatly impact the flow of the business as it would likely be a waste of time, money and supply.

"It frustrates me because they would waste my time and what I would do is just try to understand their part and would then clarify to them if they would still continue their transaction with me”. (P5)

"I have never encountered this but for me I think it's a loss because someone else could have bought your product”. (P6)

\section{Attracting Customers}

Handling a business is a difficult responsibility as it is a must that a customer is satisfied with the quality of products and services that one offers. Customer satisfaction leads to the continuous growth of your business. It contributes to building a strong relationship with your customers.

"The best thing that attracts my clients is posting the latest sneakers that are available in the market or accepting orders of hype shoes in the market, that is one factor that attracts them to buy my products". (P2)

"I attract customers through social media especially Twitter because it is where most k-pop buyers discover my store and notice that my buyers are increasing whenever I post through that app”. (P6)

Gaining personal insights about the wants of the market can effectively help the growth of the business.

"Sometimes when I'm in school I would ask them if they want to buy from me and if they're interested in my products. Sometimes I would follow some accounts so that they would be notified and informed on my online shop". (P5)

In addition, developing a connection with customers can create trust and loyalty in the relationship.

Social media has also played a big role in the lives of online business as it has created a wider range of 
markets that these small online shops can utilize.

"I use Instagram to market to PSD students". (P3)

"I use both my Instagram and Twitter account and asked my friends to spread the news about my business". (P6)

Understanding the market demands and trends will help young entrepreneurs find their way into a successful online business. Different groups have different wants and demands; hence, entrepreneurs need to understand and research their target customers. Determining the trends that would attract customers is an efficient strategy that can contribute to a successful business.

\section{Discussion}

Electronics has played a significant role in the continuous growth of the economy. With its high usage, it established the idea of putting up a business online known as e-commerce.

Electronic commerce (known as e-commerce) is a business in which information technology is used to increase sales, business efficiency and provide a basis for new products and services (Išoraite \& Miniotiené, 2018). People have grown accustomed to technology and its developments in society. Some took the step forward and seized the opportunity of starting a small business online.

Nowadays, online selling is a popular trend on any social media platform. The growth of e-commerce has contributed to the global economy with the widespread establishment of businesses online. The internet is a new shopping channel, and technology acceptance is a significant opportunity to influence consumer behavior in online shopping. By searching and sharing information and using differentiated services, online stores have an advantage in more rapid delivery, lower prices, and shorter purchasing time (Lee et al., 2011 as cited by $\mathrm{Wu}$ et al., 2018). The developments of online selling have made selling and purchasing goods and services more comfortable, accessible, and convenient for everyone.

The flourishing popularity of online selling has captivated the minds of the youth. Being raised in a modernized society, these teenagers have grown to become energetic, opportunistic, and creative individuals who are excellent skills that make an entrepreneur. Although young people can be creative, confident, and have good business ideas, sometimes brilliant ones lack funding and are scared by the bureaucracy (DogaMirzac, 2017). Nonetheless, with e-commerce, these young people are allowed to pursue their business ideas and become successful young entrepreneurs. However, being a young entrepreneur is a heavy responsibility as it is essential to learn skills such as identifying potentials, disciplining oneself, prioritizing expenses, and several more strategies.

Small business owners like the student online sellers face challenges associated with managing, financing, and balancing responsibilities. They adapt to the struggles by developing strategies that would contribute to their success as young entrepreneurs. Also, social media has played a significant role in these students' journey as it has provided them the opportunity to start a small business at an early age. Smallbusiness owners are increasingly using social media as a platform for their marketing, advertising, and recruitment activities, as well as general communications with employees, customers, and network partners (Turner \& Endres, 2017). The strategies developed while selling online have contributed to the growth of these young entrepreneurs. 


\subsection{Establishing Potentialities}

Young entrepreneurs are creative and confident in providing unique ideas in putting up a profitable business. They build their own business to identify their potentialities as an entrepreneur and in the competitive market of business (Doga-Mîrzac, 2017). The innovative ideas that the student online sellers integrate into their shop can contribute significantly to their online business's success. As an entrepreneur, one must know how to develop ideas that can support the growth of their business into the market's competitive side.

The teenagers have already shown that they do better with technology, they are more involved in social networks, and they can start a business compared to the older ones. However, there is one more difference between the two generations, the young are not attached and can quickly leave the idea of business they have created (Doga-Mîrzac, 2017). However, being able to do better with technology puts the young at an advantage in e-commerce. The student online sellers become more immersed and passionate about their business because they know how to move their way around the social media platforms.

As online platforms dominate the business industry, the population of entrepreneur minded teenagers starts to grow. They have access to an abundance of information because of the advent of technology, hence, their significant influence and demand for various products and their essential role in consumption as they do not have any fundamental financial commitments like paying rent, bills and have enough purchasing power (Chavali, 2020). However, teenagers who invest their time into online selling start to acquire the necessary financial commitments such as running an online shop. With this, they become more conscious of their spending and saving habits.

Becoming young entrepreneurs at a young age comes with various commitments, mainly financial matters. Accordingly, one has to become financially literate to continue their venture into the business field successfully. Financial matters such as financial management and budgeting play an essential role in providing long term stability and management of financial resources as it allows a person to analyze their current situation, choose alternatives and make decisions regarding their financial goals and opportunities taking control of their income (Santillan, et, al., 2019). Budgeting signifies the capability of these young entrepreneurs to discipline themselves in terms of their spending habits. It enables one to become responsible for handling the business's financial matters, which would result in a stable online business.

Budgeting has established the potential of these young entrepreneurs as they gain knowledge related to finances. Furthermore, it enables one to create various potential ideas that would contribute to the growth of their small online business. One of the most critical conditions for the sustainable entrepreneurship process is to develop high potential innovative business ideas (Özgül, 2017). Having the ability to develop a profitable business idea is vital as it would stabilize the online business. Consequently, it is a must to discipline oneself and think of the risks and possibilities of a particular business idea. As a business owner, one has to look ahead to the consequences that may result. Obtaining financial skills while doing online selling encourages the seller to become more conscious of the decisions one has to take.

Furthermore, while conducting online selling, such as budgeting, the skills obtained have shaped the student online sellers to become financially literate young adults. Financial literacy can be defined as understanding the money's language (Abdullah et al., 2017). Financial literacy has a significant impact on the financial decisions regarding their online business. Thus, these student online sellers need to learn the necessary skills that involve finances. Being financially literate can serve as a passageway for the student online sellers to establish a stable online business. It serves as an advantage for them as the financial skills would help them easily make the financial decisions that would be more efficient for their online businesses. 
Establishing a business requires an in-depth understanding of how to survive in a competitive field. Financial capabilities, business management, and market potential are aspects to look into (De Salas et al., 2017). Keeping a business afloat is a challenging responsibility as they may have several other competitors in the market. There are online businesses that are relatively similar to at least two other online shops, with the same products at the same prices. This can somehow drive online sellers to develop a more substantial business idea that would distinguish their business from the others.

One of the most effective strategies in managing a business is identifying what products to sell and whether it can profit the business. Khadka and Maharjan (2017) stated that whenever a business is about to start, customers always come "first' and then the profit. Furthermore, looking into the customer's behavior towards the products that the online business offers is essential in product development as one of the main objectives of a business is to gain customers' attention with products they would like to see in the market. Customers have a significant impact on a business's growth as they are the individuals who purchase goods and services from a business that meet their needs and wants (Khadka \& Maharjan, 2017). A business must be able to meet the expectations of the customers in order to develop a competent and sustainable business. As entrepreneurs, the student online sellers must be familiar with the market to develop competitive business ideas.

Youth are still in the middle of life choices for their future. These young entrepreneurs develop business knowledge as they immerse themselves in the business field (Finkle and Timothy, 2019). Involving oneself into the business field at an early age has contributed to developing skills that these student online sellers can use in their future endeavors. As their online business starts to grow, these student online sellers learn time management and financial management. These skills can significantly support these student online sellers as they have two different responsibilities. One as a student and the other as an online seller. As they manage to balance both responsibilities, they gain helpful insights into their future life choices.

\subsection{Acquiring Values}

Values are a vital part of an individual. It showcases the background and temperament that go beyond specific situations that one upholds. Entrepreneurs experience completely different eventualities and behaviors in every transaction (Sánchez, 2014.). The student online sellers have learned the ethics of becoming a young and independent entrepreneur by gaining values and every challenge they encounter. They learned to adapt to the world of business at a young age, which has allowed them to learn management skills that contribute to their growth as an individual.

Moreover, values are a large part of dealing with how an entrepreneur acts and manages a business. Mainly they are not only young entrepreneurs but students as well (Bogle, 2017). The multiple responsibilities they have to fulfill put pressure on these student online sellers as they weigh balancing personal life and online business. Although, despite the struggles of balancing and maintaining all their responsibilities, they continue to pursue their online business. However, the situation is overwhelming; these young entrepreneurs continue to pursue their online business as it helps them discover their capabilities of becoming successful in the years to come. Young entrepreneurs enter these business ventures with an open mind to learn new strategies and associate them with their personal lives. With this, they become flexible and responsible individuals, contributing to their independence as young adults.

The emerging influence of social media on the business industry poses an opportunity for these students to put up a business online. Becoming self-hired amongst young people is increasingly applicable in the future (Ad Rahman, 2017). These student online sellers realized the ease of establishing a business online and have decided to take the opportunity to invest their time into becoming young entrepreneurs. Growing up in social 
media, the students are at an advantage as they understand how online platforms such as Facebook and Instagram work. With this opportunity ahead of them, they start to explore the ideas of putting up an online business as they realize they can manage a business online.

Online selling reveals the capabilities of these students to become successful young entrepreneurs in the future. An excellent young entrepreneur has characteristics such as personality, sociocultural, diversity of business activities, and a strong will to develop their business (Papulová \& Papula, 2015). Being a young entrepreneur entails many opportunities for the growth of an individual. Self-development is one. They acquire values from operating their business, they become patient with their customers, and they become critical thinkers that help them think of different approaches in dealing with operating dilemmas. Their determination in developing a successful online business despite the several challenges shows their willingness to achieve great things on their own.

Acquiring business values while managing a business improves their entrepreneurial discipline in financial management and business management. Young entrepreneurs are often driven by their desires to change or become more independent in the financial aspects (Vesna et al., 2015). However, these young entrepreneurs lack the capital to start big; thus, they invest small to slowly get their targeted return, which teaches them how to be strategic and discipline in handling themselves. This helped them grow mature and independent as they learn to be careful in making decisions and taking corrective actions for their online business.

Deciding to put up a business is a big step forward for a young adult as it entails significant responsibilities. These online sellers certainly have a specific motivation in mind that drove them to be involved in the field of e-commerce. Several studies found that business activity's efficiency depends on the following psychological characteristics: the installation, motivation, risk, endurance and stamina, the strategy of behavior in failure, competitiveness, and other personal characteristics (Sandybayev, A., 2017). Some student online sellers decide to continue their venture into online business as they realize that their earnings could potentially help their family financially. Furthermore, this can be related to developing their independence as a young adult. Familial support becomes a motivating factor for these young entrepreneurs as they learn to be more conscious in spending their parent's money. These psychological characteristics can help develop a successful entrepreneur as one must have the ability to find the motivation to continue their journey into business.

Past research has indicated that students who have higher motivation are more likely to be ready to set up their ventures than those who have low motivation to engage in activities or tasks with a high degree of individual responsibility or outcomes. To motivate students towards entrepreneurial readiness, the need for achievement, independence, and the profit motive is significant (Choo \& Wong, 2006 as cited by Olugbola, 2017). Student online sellers must identify various motivating factors to guide them to continue pursuing the online business. Having motivating factors help the student online sellers to thrive despite the challenges they may encounter.

The various motives obtain a significant role for the students' entrepreneurial motivation as it encourages individuals to succeed along with their businesses. Recent studies have recognized that achievement motivation is an essential factor in encouraging individuals towards entrepreneurship (Olugbola, 2017; Coduras et al.,2016; Ismail, Ahmad, Gadar, \& Yunus, 2012). This achievement factor guides the student online sellers to handle their online business independently. With this, student online sellers can appreciate their efforts to manage their start-up business successfully. 
Previous studies also stated that desire for independence refers to personal judgment on entrepreneurial behaviors rather than being moved to act through external factors (Olugbola, 2017; Shane, 2003). Entrepreneurial behavior such as discipline and patience is a significant value that an online seller must possess as it can significantly impact the lives of their online business. This can be associated with the achievement motivation as the desire for independence is driven by the student's passion for proving that they have achieved something great in life that they can recognize on their own and by their peers and family. Being ready for entrepreneurial responsibilities can be challenging for these students. Hence, various motives must be recognized to encourage the students to continue their online business despite the challenges that may come along the way.

\subsection{Regulating Expenses}

The essence of a business is to gain profit from the products and services it offers. Hence, a business must have a strategic financial plan to determine the costs and expenses the business would encounter. With financial planning, businesses would be able to identify the gains and losses of the shop. It also concludes whether the business would succeed or fail. According to Snider \& Davies (2018), in an empirical study, Marsden, Zick, and Mayer (2011) found that individuals who worked with an adviser engaged in goal setting, calculated retirement and other needs, accumulated increased emergency funds, and had increased confidence in meeting their financial goals.

Moreover, it is necessary to consider the seller's expenses in setting a price for an item. Expenses such as shipping, packaging, and transportation are the typical expenses that an online business would encounter. Pricing is noted as one of the basic yet critical decisions a business is facing as to what price to charge customers for products and services (Kienzler, M. \& Kowalkowski, C., 2017). It is significantly critical as it stabilizes the customer value, position in the competitive market, and the ease of earning profit. Pricing strategy is significant in prioritizing the business's expenses as the prices of the products will determine whether the business is sufficiently profiting.

Also, online sellers must recognize the difference between business and personal finances. Budgeting involves identifying cash resources and optimizing financial flows (Kovalev, 2000 as cited by Sulaymonov, 2018). Distinguishing the difference between the two enables online sellers to identify methods on how to optimize their profit. Separating personal finances from business finances could prevent the loss of the business. It is also to monitor the business's gains and losses properly for it not to experience bankruptcy.

It is essential to monitor the business's expenses to assure that any financial decision will not lead to a loss. With these efficient strategies, online sellers would undoubtedly sustain the lives of their small businesses. According to Snider \& Davies (2018), Coleman, Cotei, and Farhat (2013) found that a startup's financial capital was the most critical factor in business survival. Sok, O'Cass, and Sok (2013) found that the relationships among marketing, innovation, and learning capabilities created a synergy that prevented competitors from imitating the firm, thus enhancing marketing outcomes.

\subsection{Understanding Customers}

Customers serve as the bloodline of a business, for it is their primary motivation and revenue source. Without customers, a business would not continue to exist. Customers play a significant role as they are the ones that businesses market to. Hence, satisfying the demands of the customers can significantly impact the business. Customer satisfaction is a significant factor contributing to any organization's success (Irfan, M. and Hadi, N., 2016). The customers can make or break a business as their feedback helps improve the quality of 
the products.

Due to the technological upgrading of smartphones and tablets, anyone can easily access the internet on these devices (Yulihasri, Md. Aminul Islam, cited by Richa, R. et al., 2018). However, the accessibility of the internet may have its disadvantages; online businesses can be susceptible to scam buyers. As studies conducted by The Australian Competition and Consumer Commission (2015) found that, in September 2015, $10.2 \%$ of online shopping scams reported were conducted via social media (Abul Talib, Y.Y \& Rusly, F.H., 2015). With the increase of popularity in online selling, fraudulent actions have emerged because of the easy access online shops have. Thus, online sellers need to implement a regulation that would prevent scams.

Trust is an essential element in the buyer and seller relationship. However, online sellers must be careful in trusting some buyers as they may be a scam. The student online sellers have created a strategy that would help identify whether the buyer is real or not. This strategy enables them to become more cautious in accepting customers' orders by checking the buyer's profile and prohibiting the cancellation of orders. Developing such a strategy has eased their experience in online selling. Subsequently, most online shops nowadays use Instagram as their platform. Online transaction through social media is a media to facilitate buyer and seller interactions (Amelia, 2016). Through Instagram, the student online sellers go over the necessary information of their buyer's profile, and with this, they can validate their buyers' intentions. This strategy helps create a successful relationship between the buyer and seller relationships as it builds the trust and security of both parties.

Establishing a successful buyer and seller relationship by connecting and communicating effectively provides online sellers a broader perspective on the market's demands. Consequently, this strategy keeps the business on the market's competitive side as they know the market demands. They are utilizing the social media platforms that shaped these online businesses to become more competitive as online businesses' population increases over the years. Moreover, due to their nature as interactive and modern technology (Web 2.0), social media ads represent the firm's cutting edge-customer communication (Logan, Bright, \& Gangadharbatla, 2012 as cited by Alalwan, A.A, 2018). Through the various social media platforms, customers can easily interact with the seller, which helps create loyalty and trust as both sides can communicate effectively. Attracting customers through social media has helped the business gain knowledge on the customer's demands, shape the customer's perception and motivate customers to purchase the product.

Customer insights enable the business to firmly align its resources with the market (Carson et al., 2020). Developing an efficient marketing strategy is considered a crucial step in developing a small online business because of the limited capability of small businesses. However, formulating market strategies that allow them to interact with their buyers personally and online allowed these online sellers to create customer value and quality products. This concludes that online business has become popular and easy to manipulate the market's needs and wants through the use of online marketing. Furthermore, to create an effective marketing strategy, the business must have the patience to undergo the struggles encountered in online selling.

Entrepreneurial marketing in online businesses reflects the flexible and emergent use of resources (Anwar, M.N. and Daniel, E., 2016). The student online sellers have integrated an efficient marketing strategy by connecting with their customers personally. They take advantage of any opportunities to market their small business, either through communicating with their fellow students and friends or using their social media accounts. 


\section{Conclusion}

With the prominent emerging influence of technology and social media, businesses start to boost as they extend their market online. Social media became a huge deal player for online businesses. It increases the marketing strategies to boost and increase a brand's sales (Henderson, 2020). The formation of e-commerce presented society with a convenient and accessible means of exchanging, selling, and purchasing products. It built better opportunities and potential to develop mere individuals into successful entrepreneurs.

E-commerce is a convenient device for entrepreneurs who actively engage in digital technology and services to create their business ventures (Bican \& Brem, 2020). This enables many individuals to quickly put up a business as it requires a low set up. Moreover, social media provides reachable opportunities for startup entrepreneurs as they consider its low-cost financing and budget-friendly approach, especially to young entrepreneurs like the students.

Various social media platforms are available for these student online sellers to set up a business, such as Instagram, Facebook, and Twitter, which these young adults often use. The significant growth of the cellular era, social apps, and the cloud have created possibilities for various online entrepreneurs to enter global technology entrepreneurship at a low cost (Finkle \& Olsen, 2019). Establishing a business at their age has its advantages as their familiarity with social media can help develop innovative and profitable business ideas.

Online selling offers an excellent opportunity for a young entrepreneur as their online business can reach a broader market than a physical store. E-commerce is a flexible platform to start in for young and startup entrepreneurs looking for a great place to venture in; unlike traditional stores, an e-commerce business platform does not need a physical presence to run the business (Bican \& Brem, 2020). Their familiarity with social media platforms and the accessibility of establishing an online business creates an advantage for them to start entrepreneurial opportunities at a young age.

However, despite the endless opportunities that an online business entails, challenges may occur along the way, and one has to learn to endure the hardship and pursue their goals for the online business. Moreover, the challenges an online seller may encounter contribute to the business's growth as they learn to develop strategies that would keep the business afloat despite the struggles.

The challenges faced by the student online sellers have significantly impacted their growth as an online seller as they learn to cope with the struggle and can develop efficient strategies that will help them in overcoming such in the future. Their experiences gradually taught them to think ahead of the possible risks encountered in the business. Through online selling, they were able to attain the necessary skills that a successful entrepreneur must possess. Handling a business at a young age serves as a transcendent opportunity for these students as it molds them to become mature and successful individuals for the future. Online selling opened the doors for the students as the strategies they develop benefit their business and their personal lives.

Based on this study's simulacrum, student online sellers developed four significant strategies that significantly impacted their online business growth. (1) Establishing Potentialities (2) Acquiring Values (3) 
Regulating Expenses (4) Understanding Customers. The study emphasizes the strategies that have contributed to online business growth among student online sellers. Furthermore, the strategies were thoroughly discussed while various challenges were identified. Through the identified challenges, student online sellers were able to develop the four major strategies that contribute to their online business growth. These strategies play a crucial role because it maintains the business's life and keeps the online sellers motivated to continue their business ventures.

The researchers recommend future related studies to further expand on the concept of e-commerce and its influence on young adults like the student online sellers. The researchers suggest focusing on the various opportunities that e-commerce has provided for the youth. In conducting a similar study, it is highly advised to use various online businesses to scrutinize whether all online sellers would answer the same ideas.

Moreover, aspiring young entrepreneurs are highly recommended to learn how to balance both roles in being part of a competitive business field and being a student. The researchers commend the student online sellers for overcoming the challenges that face them and their incredible determination in pursuing a successful online business.

\section{References}

Abdul Talib, Y. Y., \& Rusly, F. H. (2015). Falling Prey for Social Media Shopping Frauds: The Victims' Perspective. International Conference on E-commerce. Retrieved from http://repo.uum.edu.my/17543/1/27_ICoEC2015\%20185-189.pdf

Abdullah, S., Mohammed, N. H., Salleh, S. M., Rashid, K. M., \& Kamal, S. S. (2017). Financial Literacy among UiTM's Students. TEXTROAD Journals. Retrieved from https://www.textroad.com/pdf/JAEBS/J.\%20Appl.\%20Environ.\%20Biol.\%20Sci.,\%207(5S)31 36,\%202017.pdf

Ad Rahman, A. A., Muhammad, N., \& Ridzwan, R. (2017). Issues and Challenges among Young Entrepreneurs in Malaysia. from: https://pdfs.semanticscholar.org/f160/3cf984043a7331cab8711e3542048d240f0a.pdf

Alalwan, A. A. (2018). Investigating the impact of social media advertising features on customer purchase intention. International Journal of Information Management, 42, 65-77. Doi: https://doi.org/10.1016/j.ijinfomgt.2018.06.001

Amelia, T. N. (2016). Fraud in online transaction: Case of Instagram. Journal of Advanced Management Science, 347-350. Doi: https://doi.org/10.12720/joams.4.4.347-350

Anwar, M.N. and Daniel, E. (2016), "Entrepreneurial marketing in online businesses: The case of ethnic minority entrepreneurs in the UK". Qualitative Market Research, 19(3), 310-338. https://doi.org/10.1108/QMR-04-2015-0029 
Bican, P. M., \& Brem, A. (2020). Digital Business Model, Digital Transformation, Digital Entrepreneurship: Is There A Sustainable "Digital"? Sustainability, 12(13), 5239. Retrieved from http://dx.doi.org.eres.qnl.qa/10.3390/su12135239

Bogle, J. C. (2017). Balancing professional values and business values. Financial Analysts Journal, 73(2), 1423. Retrieved from https://search-proquest-com.eres.qnl.qa/scholarly-journals/balancingprofessional-values-business/docview/1925376856/se-2?accountid=49936

Carson, G., O'Connor, C. \& Simmons, G. (2020). The crucial role of market intelligence in the development of small business marketing capabilities. Journal of Small Business and Enterprise Development, 27(5),797-816. Doi: https://doi.org/10.1108/JSBED-12-2019-0394

Chavali, K. (2020). Saving and spending habits of youth in Sultanate of Oman. Journal of critical reviews, 7(2). Retrieved from https://doi.org/10.31838/jcr.07.02.132

De Salas, K., Lewis, I. J., \& Huxley, C. (2017). Using the critical process targeting method to improve SMEs' process understanding: A tale of two Australian case studies. Business Process Management Journal, 23(2), 425-447. Doi: https://doi.org/10.1108/BPMJ-06-2014-0052

Doga-Mîrzac, Mariana. (2017). The Promotion of Young Entrepreneurs for Development Small and Medium Business. Valahian Journal of Economic Studies. 8. Doi:49-56. 10.1515/vjes-2017-0018.

Elnaga A., \& Al Shammari, F. (2016). The Impact of E-commerce on Business Strategy: A Literature Review Approach. Journal of American Science. Retrieved from http://www.jofamericanscience.org/journals/am-sci/am120516/08_30069jas120516_68_79.pdf

Finkle, T. A., \& Timothy, O. (2019). Entrepreneurship in the Digital Era: Creating your own online business. ResearchGate. Retrieved from https://www.researchgate.net/publication/326506804_Entrepreneurship_in_the_Digital_Era_Creatin g_Your_Own_Online_Business

Hartley, J. (2016). Why Sell Online? The Importance of eCommerce in Your Sales Strategy. Retrieved from https://www.business2community.com/ecommerce/sell-online-importance-ecommerce-salesstrategy01415866\#: :text=Benefits,your\%20brick\%20and\%20mortar\%20location.\&text=Even\%20if\%20yo ur\%20product(s,help\%20buyers\%20discover\%20your\%20business.

Henderson, G. (2020). The importance of social media marketing. DigitalMarketing.org. https://www.digitalmarketing.org/blog/the-importance-of-social-media-marketing

Irfan, M., Shamsudin, M., \& Hadi, N. U. (2016). How important is customer satisfaction? Quantitative evidence from mobile telecommunication market. ResearchGate. Retrieved from 
https://www.researchgate.net/publication/303550723_How_Important_Is_Customer_Satisfaction_Q uantitative_Evidence_from_Mobile_Telecommunication_Market

Išoraitè, M., \& Miniotienè, N. (2018, June 4). Electronic commerce: Theory and practice. ResearchGate. Retrieved from https://www.researchgate.net/publication/329704574_Electronic_Commerce_Theory_and_Practice

Khadka, K. \& Maharjan, S. (2017). Customer Satisfaction and Customer Loyalty. Centria University of Applied Sciences. Retrieved from https://core.ac.uk/download/pdf/161421179.pdf

Kienzler, M., \& Kowalkowski, C. (2017). Pricing strategy: A review of 22 years of marketing research. ResearchGate. Retrieved

from https://www.researchgate.net/publication/316861311_Pricing_strategy_A_review_of_22_years_of_ marketing_research.

Olugbola, S. A. (2017). Exploring entrepreneurial readiness of youth and startup success components: Entrepreneurship training as a moderator. Journal of Innovation \& Knowledge, 2(3), 155-171. Doi: https://doi.org/10.1016/j.jik.2016.12.004

Ou, R. (2016). Privacy perception of online shopping behavior between millennials and non-millennials in Chinese digital marketing. Repository University of Twente Student Theses. Retrieved from https://essay.utwente.nl/70365/1/Bachelor\%20Thesis-Ran\%20Ous1425080.pdf?fbclid=IwAR3E1CLo116X9av2r4cYKCdHhcRghPYYnW4rSBIMMULkF39pHEKfqKQdbs

Özgül, E., \& Turan, N. (2017). Obstacles of the development of innovative business ideas: A survey on students of entrepreneurship education. ResearchGate. Retrieved from https://www.researchgate.net/publication/329916774_Obstacles_of_the_Development_of_Innovativ e_Business_Ideas_A_Survey_on_Students_of_Entrepreneurship_Education.

Packer, M. J. (2017). The science of qualitative research. Higher Education from Cambridge University Press. https://www.cambridge.org/highereducation/books/science-of-qualitativeresearch/4BB8E074ACDD0CC27A53935761129C9A

Papulová, Z., \& Papula, J. (2015). Entrepreneurship in the Eyes of the Young Generation. Retrieved from https://www.sciencedirect.com/science/article/pii/S2212567115016627.

Punia, S. K. (2016). Social media: Political campaigns and elections. Retrieved from https://go.gale.com/ps/anonymous?id=GALE\%7CA558368335\&sid=googleScholar\&v=2.1\&it=r\&li nkaccess $=$ abs $\&$ issn $=0973855 \mathrm{X} \& \mathrm{p}=\mathrm{AONE} \& \mathrm{sw}=\mathrm{w}$ 
Ravichandran, K., Arulchelvan, S., \& PeriyaKannan, K. (2018). Journal of media and communication studies. Academic Journals. https://academicjournals.org/journal/JMCS/article-full-text/F8D522959043

Richa, Ranjan \& Kukreti, Ankur \& Mittal, Sachin. (2018). Effects of online shoppingon comsumer buying behaviour. Doi: 10.13140/RG.2.2.14183.96167.

Sánchez, A. C. (2014). The Role of Personal Values in the Entrepreneurial Process. Tesis Doctorals en Xarxa: TDX Home. Retrieved from https://www.tesisenred.net/bitstream/handle/10803/289568/ACS_PhD_THESIS.pdf?sequence=1

Sandybayev, A. (2017). Entrepreneurial motivations as determinants of youth entrepreneurship challenges: A case of business college in UAE. ResearchGate. Retrieved from https://www.researchgate.net/publication/323264685_Entrepreneurial_Motivations_as_Determinants _of_Youth_Entrepreneurship_Challenges_A_Case_of_Business_College_in_UAE.

Santillán, A. G., Lobato, T. Z., \& Hernandez, J. R. (2019). Budget plan to manage income and expenses in college students: Some features that explain it. ResearchGate. https://www.researchgate.net/publication/334467277_Budget_Plan_to_Manage_Income_and_Expen ses_in_College_Students_Some_Features_that_Explain_It

Snider, J. H., \& Davies, K. J. (2018). Success Strategies for Small Financial Planning Firms. Scholar Works | Walden University Research. https://scholarworks. waldenu.edu/cgi/viewcontent.cgi?article=1143\&context=ijamt

Sok, Phyra \& O'Cass, Aron \& Sok, Keo. (2013). Achieving superior SME performance: Overarching role of marketing, innovation, and learning capabilities. Australasian Marketing Journal (AMJ). 21. 161167. 10.1016/j.ausmj.2013.04.001.

Sulaymonov, A. (2018). Importance of budgeting ant its role in strategic management accounting. Retrieved from https://www.researchgate.net/publication/338984565_Importance_of_budgeting_ant_its_role_in_stra tegic_management_accounting.

Turner, S., Endres, A. (2017). Strategies for Enhancing Small-Business Owners' Success Rates. International Journal of Applied Management and Technology, 16(1), 34-49. Doi:10.5590/IJAMT.2017.16.1.03

Vallesteros, F.D.J., Dela Cruz, A., Delavin, A., Merced, A., Platitas, A., Tubello, J., (2020). The Long Way Home: The Social Diagraming of Philippine School Doha Alumni in the Philippines. International Journal of Science and Research (IJSR). Retrieved from https://pdfs.semanticscholar.org/3489/ba433840e6edefcdb77777f1de171a70360a.pdf 
Vallesteros, F. D. J., Dipasupil, P. A. E., Gamayon, R. A., Bautista, D. G., De Guzman, J. N., Milan E. (2020). Leaving the Daylight: The Adjustments of Filipino Night Shift Workers in the State of Qatar. International Journal of Science and Research (IJSR). Retrieved from https://pdfs.semanticscholar.org/64a4/6a959a3f75e5ab16ae0cdb7c7bcf025803a3.pdf

Vesna, V., Drobnjak, R., \& Reyhani, M. (2015). Opportunities and challenges in promoting youth entrepreneurship in Montenegro. from https://www.econstor.eu/bitstream/10419/144660/1/848625323.pdf

Willig, C. (2016). Constructivism and 'The Real World': Can they co-exist? City Research Online - Welcome to City Research Online. https://openaccess.city.ac.uk/id/eprint/13576/1/QMiP\%20\%27View\%20from\%20the\%20top\%27\%2 03.pdf

Wu, W. Y., Ke, C. C., \& Nguyen, P. T. (2018). (PDF) Online shopping behavior in electronic commerce: An integrative model from utilitarian and hedonic perspective. ResearchGate. Retrieved from https://www.researchgate.net/publication/328569982_Online_Shopping_Behavior_in_Electronic_Co mmerce_An_Integrative_Model_from_Utilitarian_and_Hedonic_Perspective 


\section{Words of Gratitude}

This study's success will not be possible without the support, assistance, and guidance of some individuals who contributed their time and effort. Their knowledge is a vital factor for us to gather much needed information. They gave us a great opportunity to share our endeavors and accomplishments. With that, we would like to show our appreciation to:

Ms. Joan Marie Alegario, MST, our Research Adviser, for her continued support and aid throughout this process. Providing guidelines to lead us on the right track upon developing this research project. She has shared her skills and expertise to be able for us to provide accurate information. Her dedication by giving her time to share IMRAD skills among her students. For all the encouragement and motivation, as there are times that we are out of focus. She is truly an experienced and trusted mentor that administers all the advice we need. Without her, we would not be able to show our full potential and talent. This research is achievable because of her in-depth knowledge and greater heights of learning.

Dr. Alexander S. Acosta, our dear school principal, for his provision to this Research and never-ending reassurance.

Dr. Noemi F. Formaran, our SHS vice-principal, for her encouraging words of wisdom and absolute support all throughout this paper.

Our participants, the senior high school students, for their time and cooperation in being a vital aspect of our study. They truly are the core of this research's victory.

Our teachers in the Senior High School Department, for their motivation and inspiration for us to achieve our goals.

Our peers and colleagues, for being the backbone throughout our journey in making this paper.

Our family and friends, for being an inspiration for us to approach the victory that lies ahead.

Finally, the Almighty God who became our enlightenment, strength, and provider of wisdom that he continues to bless us with. 


\section{Biographical Sketch}
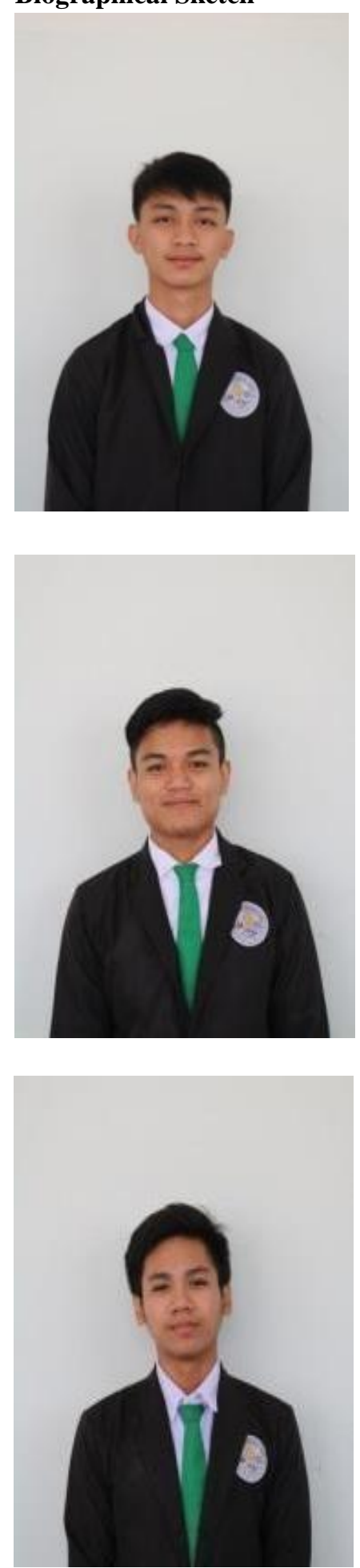

James Bryan M. Bondad was born on March 26, 2003, in Calamba, Laguna. He is currently a Senior High School Student under the academic track ABM (Accountancy, Business, and Management) at Philippine School Doha. He studied at Philippine International-School Qatar where he learned and excelled in athletic fields such as basketball leagues in the said school. After moving to Philippine School Doha during his Grade 10 Junior High School, he continues to pursue his passion for playing basketball. Engaging in sports activities of the school such as Intramurals and PTA organized events. He is a consistent student-athlete of the schools he has attended. Moreover, he is a family person and a trustworthy friend to others. The people around him serve as his inspiration to pursue his passion for his hobbies. Throughout his life, he has encountered several hardships, however, he continues to be motivated and strive to reach his goals, aspiring to be an entrepreneur someday. He is planning to pursue a Bachelor of Science in Entrepreneurship at Malayan College Laguna.

Frank Gio S. Cruz was born on February 15, 2002, in Manila, Philippines. He is currently a Senior High School Student under the academic track ABM (Accountancy, Business, and Management) at Philippine School Doha. He participates in various extra-curricular activities such as the Intramurals where he contributed to the team by becoming the Most Valuable Player (MVP) and being part of the Mythical 5. He also received acknowledgment for being Best in Research during his Junior High School. He exhibits the personality of a team player and strong determination skills. He is a student determined to prove his potentialities in academics and non-academic fields. persevering his dreams to serve and save others aspiring to be a future paramedic. He is planning to pursue a Diploma in Advanced Care Paramedicine at the College of North Atlantic - Qatar.

Ralph Fredie M. Tomas was born on April 18, 2003, in Manila, Philippines. He is currently a Senior High School Student under the academic track ABM (Accountancy, Business, and Management) at Philippine School Doha. He gained a reputation in academic and non-academic fields when he studied at Philippine International-School Qatar. Moreover, he is a dependable and trustworthy friend to others. With this, he is a consistent part of the Basketball intramurals where he showed passion and determination in his field. He also participated and won 2 times in a CSGO International Tournament which was held at Virtuo City, Doha Festival City. With all the skills and experiences he gained, he aspires to be a businessman and an accountant in the future and planning to pursue a Bachelor of Business Management at National University. 

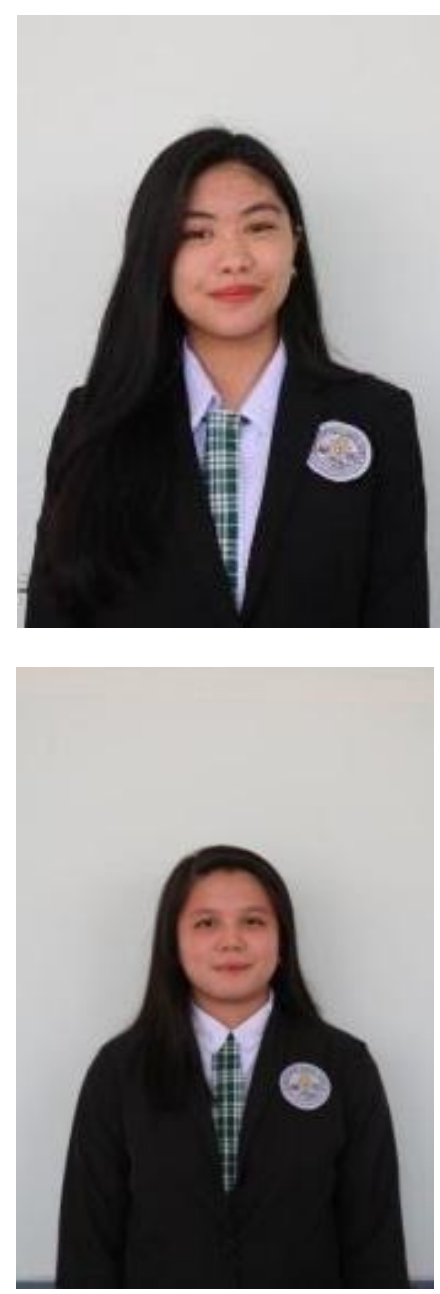

Angela Nina J. Aldover was born on April 5, 2003, in Batangas city. She is currently a Senior High School Student under the academic track ABM (Accountancy, Business, and Management) at Philippine School Doha. She is a consistent top achiever in her class. During her Junior High School convocation, she was one of the bronze awardees of the batch. She is also a member of the PSD Chorale where she shares her talent in singing and passion, continuously proving her academic excellence she received a laureola bronze award during the second semester of her grade 11, with these achievements and experiences motivate her to work hard with perseverance and determination. Throughout her life, she has gone through ups and downs, yet she strives to continue with life. Driven to become an aspiring CPA in the future she is planning to pursue a Bachelor of Science in Accountancy at the University of Santo Tomas. Being determined and passionate about everything she does is one of the reasons why she has achieved a positive attitude towards life.

Genale Audrey V. Calpito was born on September 10, 2002, in Batangas City, Philippines. She is currently a Senior High School Student under the academic track ABM (Accountancy, Business, and Management) at Philippine School Doha. She has studied from various schools such as Philippine International-School Qatar where she was molded into the student she is today. During her Junior High School convocation, she was awarded with an academic distinction which motivated her to achieve greater things in life. Currently, she has been consistently garnering academic awards in her class and has been a consistent member of the top 10 . She was also a member of the Basketball Girls varsity and was the president of the group in her previous schools and has continued her passion for sports when she arrived in Philippine School Doha. She is a passionate student who strives to achieve greatness in everything she has been assigned to do. Dedicated to starting her own business venture and learning new business ideas, she aspires to be an entrepreneur in the future. She is planning to pursue a Bachelor of Science in Business Management at the Ateneo De Manila University.

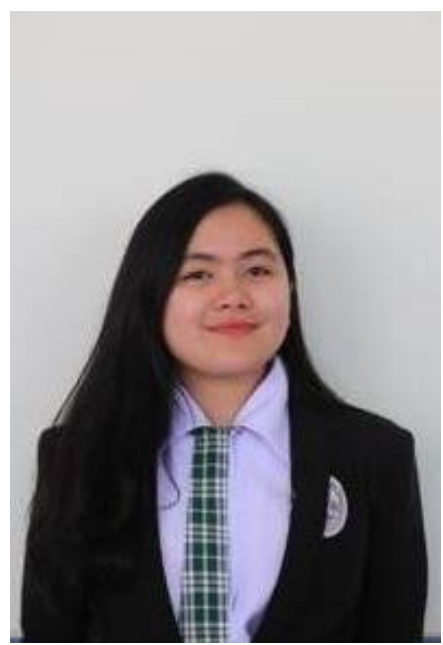

Julianne Kyle A. Cañeso was born on September 18, 2002, in Muntinlupa City, Manila, Philippines. She is currently a Senior High School Student under the academic track ABM (Accountancy, Business, and Management) at Philippine School Doha. She transferred to Doha, Qatar when she turned to 4-year-old then starting grade one up to present she studied in Philippine School Doha. During her elementary years, she has been a consistent honor student. She is the youngest in her family and grew up independently since she was still a kid. At an early age, she manages to take care of her own. During her junior year, she learned how to cope with pressure and face her anxieties. She was also an officer in C.AT. (Citizenship Advancement Training), the group which takes all the responsibilities and help the people 
in their school. She learned to be patient and understanding which made her acknowledged her award which is during her Convocation she received the Cadet Officer of the Year award. Dedicated to rendering service to the welfare of the people. She is an aspiring Nurse, planning to pursue a Bachelor of Science in Nursing at the University of Santos Tomas.
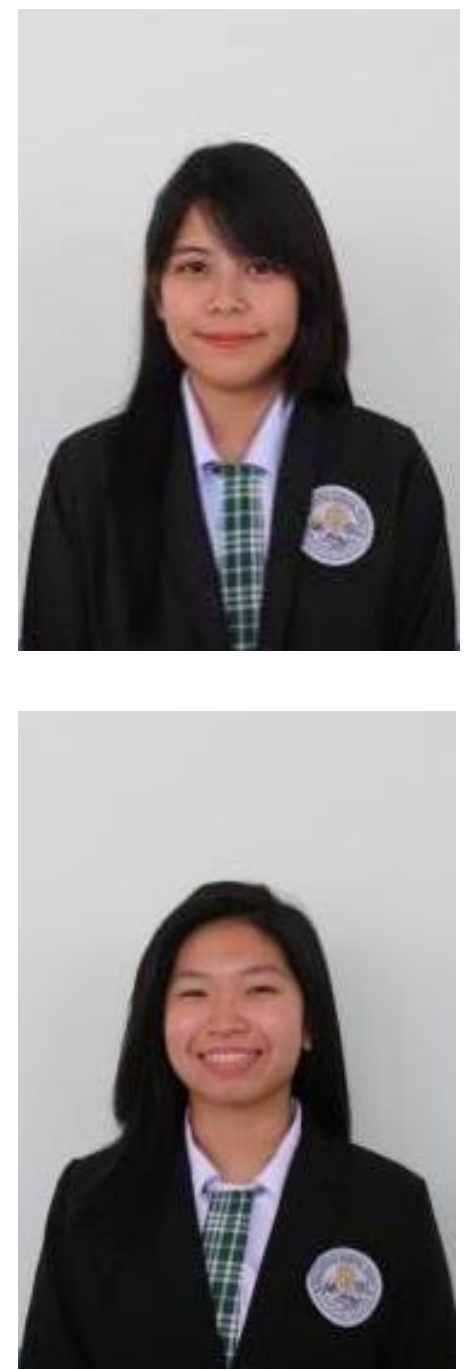

Gabrielle Mogene D. Olaes was born on April 12, 2003 in Kawit Cavite, Philippines. She is currently a Senior High School Student under the academic track ABM (Accountancy, Business, and Management) at Philippine School Doha. She always focuses on her studies and can balance her social life with her academics. She is shy but has a lot of potentials within her. Throughout her elementary days, she was a First Runner Up in Poster Making. During her junior year, she has been a consistent honor student. Continuously proving her academic excellence, she is a constant Laureola awardee from her first semester to her second semester of her Garde 11. After her graduation, this 2021, she plans to pursue a Bachelor of Science in Accountancy at the Ateneo De Manila University.

Elysha Reigne S. Santos was born on July 10, 2003, in Marikina City. She is currently a Senior High School Student under the academic track ABM (Accountancy, Business, and Management) at Philippine School Doha. In line with her strand, she has achieved various seminars for financial management. She is a member of COL financial where she practices her knowledge in investing and stocks. During her grade 10, she dedicated her service as a C.A.T officer where she received an award of Cadet Officer of the Year. Aside from her dedication to service, she is also an enthusiast of sports wherein she uses her various sports training in competing inside and outside school competitions. She is a believer of hard work and perseverance, dedicated to what she desires to be, motivated to become a Digital Advertising Manager in the future. She is planning to pursue a Bachelor of Science in Advertising Management at the De La Salle University. 